\title{
Chemical Characteristics and Fatty acid Composition of Cucurbitaceae Oils from Cameroon
}

\author{
$\underline{\text { Achu, M. B., }{ }^{1 *} \text { Fokou, E., }}{ }^{1}$ Tchiégang, C., ${ }^{2}$ Fotso, M., ${ }^{3}$ \& Tchouanguep, M.F. ${ }^{4}$ \\ ${ }^{1}$ Department of Biochemistry, Faculty of Science, P. O. Box 812, University of Yaoundé I, Cameroon \\ Correspondent: e-mail: lohmercy@yahoo.fr \\ ${ }^{2}$ Department of Food Science and Nutrition, ENSAI/IUT, Ngaoundéré, Cameroon \\ ${ }^{3}$ Centre for Research in Food and Nutrition, IMPM, Yaoundé, Cameroon. \\ ${ }^{4}$ Department of Biochemistry, Faculty of Science, University of Dschang, Cameroon
}

\begin{abstract}
This work analyses the acid, saponification, iodine and peroxide indices, and the fatty acid composition of five Cucurbitaceae (egusi) seed oils from different regions in Cameroon. These seeds are Cucumeropsis mannii (egusi melon), Cucurbita maxima (pumpkin), Cucurbita moschata (musk melon), Lagenaria siceraria (calabash) and Cucumis sativus ("Ibo"egusi). The results show that the saponification, iodine and peroxide indices are influenced by the regions while the acid index and percentage of impurity do not depend on the region of cultivation but on the specie. The values for the indices are as follows: The acid index ranges from 3 - 10; iodine, 83 - 114; saponification, $204-231$ and peroxide, 3 8 m.equiv.g of $\mathrm{O}_{2} / \mathrm{g}$ of oil. These values are within recommended levels for edible oils. These oils have 4 main fatty acids: Palmitic, stearic, oleic and linoleic acid, the most abundant being linoleic acid (48-69.13\%). The fatty acid profile is C18:2 > C18:1 > C18:0 in all the samples, irrespective of the origin. Their chemical properties are similar to those of corn, cottonseed, sesame and sunflower seed oils. These results suggest that they can be good for table, cooking and frying oils and for making mayonnaise. The high linoleic acid level makes them good oils for the fight against cardiovascular illnesses.
\end{abstract}

Key Words: Cucurbitaceae, oils, fatty acids, acid, saponification, iodine, peroxide, indices.

\section{INTRODUCTION}

The Cucurbitaceae family has a tremendous genetic diversity, extending to vegetative and reproductive characteristics $(\mathrm{Ng}, 1993)$. They grow in tropical, subtropical, arid deserts, and temperate locations. The plants of the five varieties studied are annual, herbaceous, monoecious plants with climbing or creeping stems. After planting, they completely cover the soil surface within 4 weeks of growth, thus helping in weed control. Pollination is by insects. Flowering occurs about 4-5 weeks and fruits mature at 7-8 weeks after planting (Oil Crops, 2000). The fruits are indehiscent smooth berries, are very large and seedy and when sound, can be stored for over a year, or the seeds can be removed, washed and dried. For use, they are decorticated, ground into a nutritious oily meal and cooked. The seeds contain about $50 \%$ oil (Martin,1998), 42-57.34\% oil (Fokou et al., 2004), 44-53.76\% oil for seeds cultivated in different bioclimatic regions in Cameroon (Achu et al., 2005). These studies show that these seeds contain good amounts of oil that can be exploited. Most of the oil is made up of unsaturated fatty acids with high amounts of essential fatty acids, especially linoleic acid, 68.5\% (Kinkela, 1990). Pumpkin seed oils also have antihelmintic properties (Veljkovic, 1992). Considering this high nutritional value of egusi seed oils, they are still underexploited industrially in Cameroon. The aim of this work is to find out some of the chemical properties (acid, saponification, iodine, peroxide indices) and fatty acid composition of oils extracted from egusi seeds from Cameroon, which can be exploited at the industrial and alimentary levels, with the eventual production and use of egusi seed oil. This will also lead to increased 
production, consumption and sale of these seeds especially in the rural areas where farming is the main occupation of the women, thus helping to improve their health and financial status.

\section{Sample collection and treatment}

\section{MATERIALS AND METHODS}

The samples were collected from different bioclimatic regions of cultivation throughout Cameroon. These are Sahel, High Savanna, Rain forest and Swamp forest regions (Table 1). The seeds were bought already dried under local conditions by the farmers, transported in polyethylene bags to the laboratory, cleaned with filter paper and dried in an Oven at $70^{\circ} \mathrm{C}$ to constant weight. They were ground in an electric grinder, put in airtight bottles and stored in the desiccator for analyses.

Table 1: Regions of Collection of Egusi Seeds

\begin{tabular}{|clll|}
\hline Sample & \multicolumn{1}{c}{ Region } & Province & Town or Village \\
\hline & High Savanna & North West & Bali \\
& High Savanna & West & Bantoum \\
Cucumeropsis & High Savanna & Adamawa & Ngaoundale \\
mannii & Rain Forest & South & Ebolowa \\
& Rain Forest & East & Abong-Mbang \\
& Swamp Forest & South West & Muea \\
\hline \multirow{2}{*}{ Cucurbita } & High Savanna & North West & Santa \\
maxima & High Savanna & West & Galim \\
& Rain Forest & Centre & Yambassa \\
\hline \multirow{2}{*}{ Cucurbita } & High Savanna & North West & Mankon \\
moschata & High Savanna & West & Bafounda \\
& Rain Forest & Centre & Yambassa \\
& Swamp Forest & South West & Muea \\
\hline \multirow{2}{*}{ Lagenaria } & Sahel Savanna & Far North & Yagoua \\
siceraria & High Savanna & North West & Zhoa \\
& High Savanna & West & Bafoussam \\
& Swamp Forest & Littoral & Douala \\
\hline \multirow{2}{*}{ Cucumis } & High Savanna & West & Bazou \\
sativus & High Savanna & Adamawa & Tignere \\
& Rain Forest & Centre & Bafia \\
& Swamp Forest & South West & Muyuka \\
& Swamp Forest & Littoral & Japoma \\
\hline
\end{tabular}




\section{Methods of Analysis}

Oils were extracted from the seeds by continuous extraction in a Soxhlet apparatus for 8 hours using hexane as solvent (AOAC, 1980). The acid, saponification, iodine and peroxide indices of the oils were determined by colorimetric methods (AFNOR, 1981) and the fatty acids by Gas Liquid Chromatography. Data were analysed using the SPSS 9.0 software. ANOVA was used to find the correlation between the parameters measured and the regions of cultivation of the seeds. Also ANOVA and the Kruskal-Wallis tests were used to find differences between the indices and fatty acids of oils from the various species of seeds. The Student-NewmanKeuls (S-N-K) test was used to locate these differences. The tests were done at the $5 \%$ level of significance.

\section{RESULTS}

The results of analyses are shown on Tables 2 and 3 below. Each result is a mean of three replications per sample according to the region of cultivation. The average for each specie of seed from the different regions is given as Mean \pm Standard deviation (SD). All the oils are liquid at room temperature.

Table 2 shows the parameters for oil quality. The acid index and the percentage of impurity do not depend on the region of cultivation but on the specie while the saponification, iodine and peroxide indices are influenced by their regions of cultivation $(p<0.05)$. There is a significant difference $(\mathrm{p}<0.05)$ in the acid, iodine, peroxide indices and percentage of impurity but no significant difference in the saponification index of the different species of seeds.

Table 3 shows the fatty acid composition of the egusi oils. The Kruskal-Wallis test reveals that there is no significant difference in the levels of C12:0, C14:0, C16:1, C20:2, unsaturated fatty acids and $\mathrm{R}_{1}$ (\% saturated fatty acids / \% unsaturated fatty acids) values, while the rest of the fatty acid values show a significant difference $(p<0.05)$ in the 5 samples studied. 


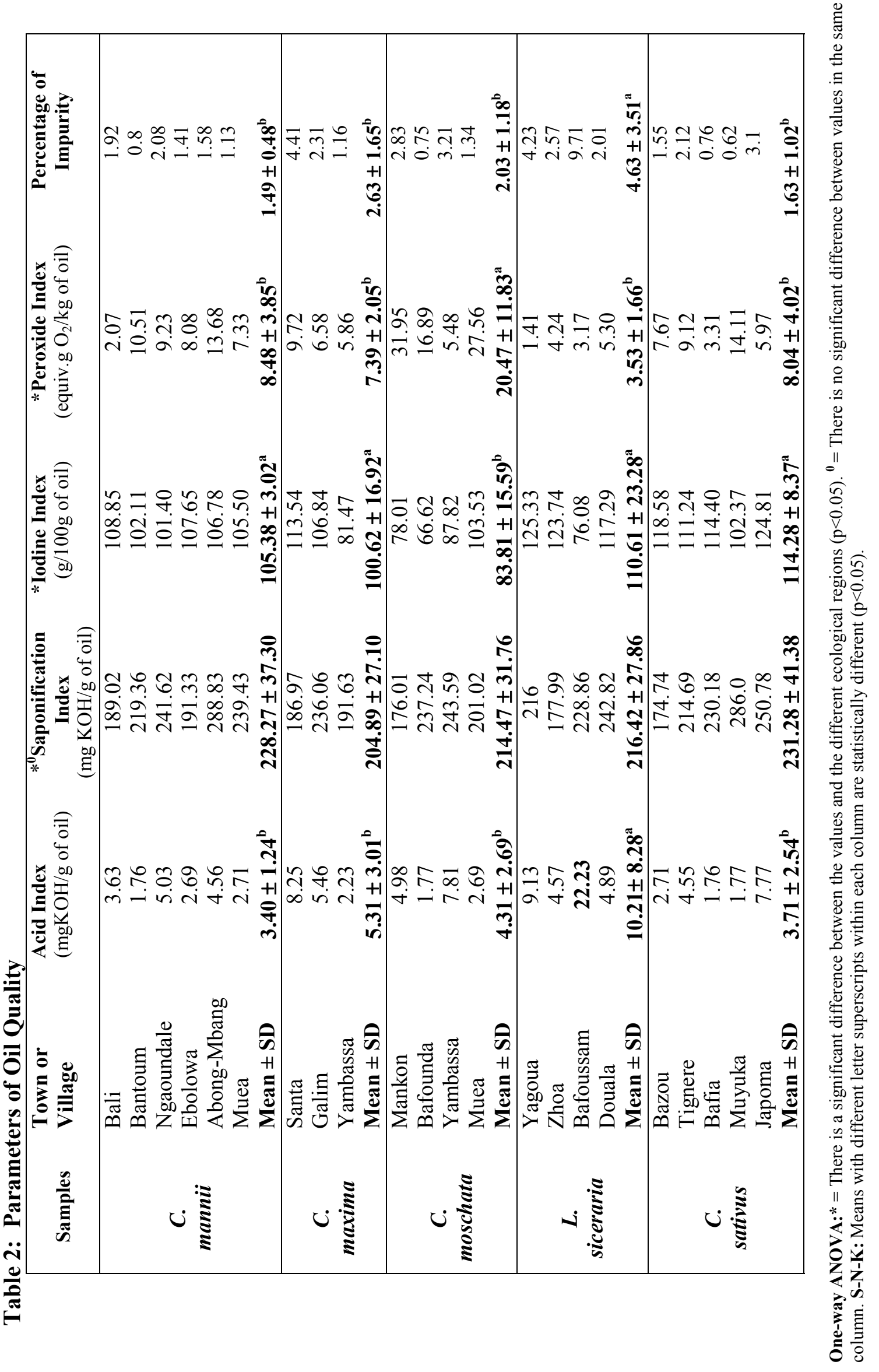




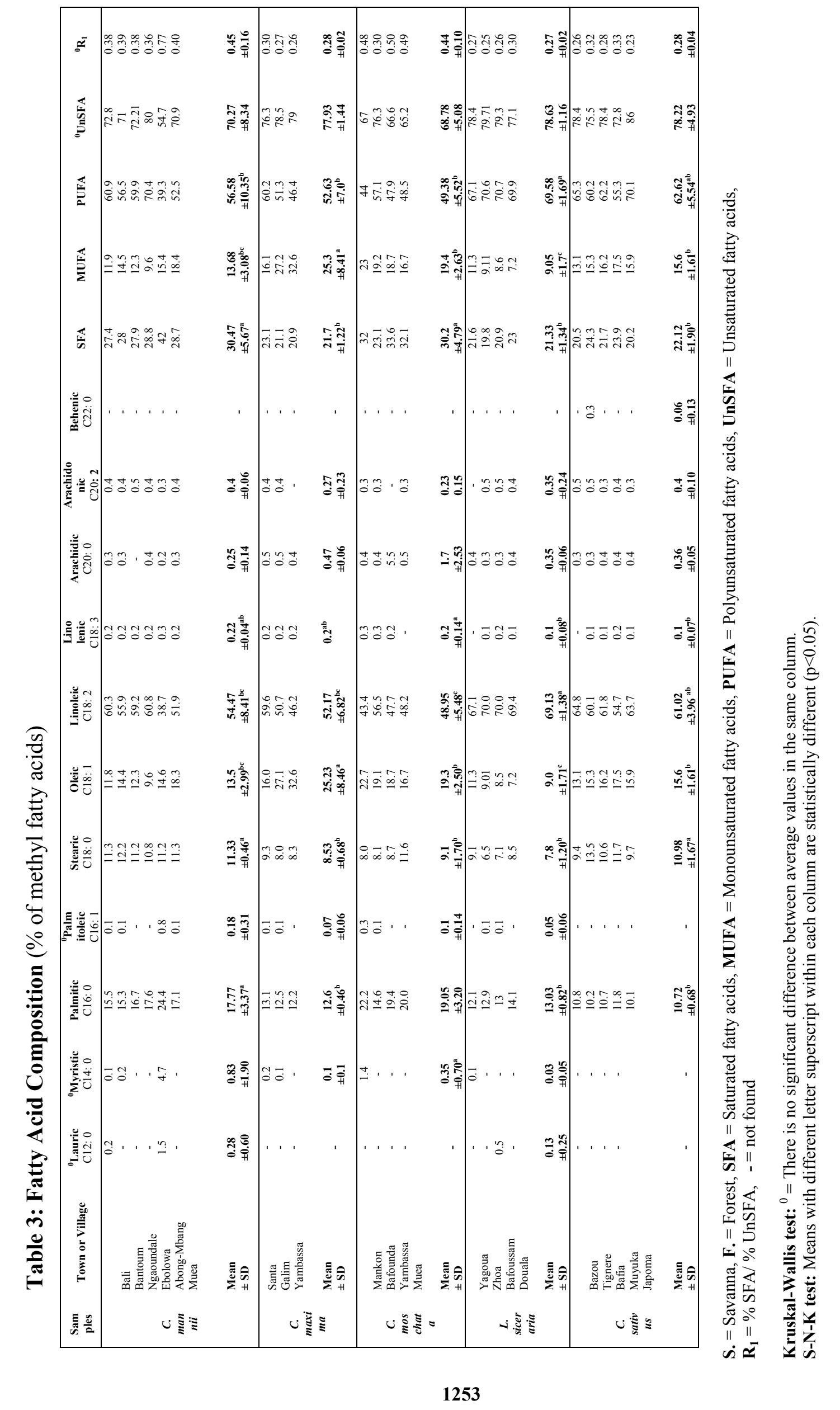




\section{DISCUSSIONS}

The acid index of the samples ranges from 3 (C. mannii) to 10 (L. siceraria). The acid index of L. siceraria is significantly higher $(\mathrm{p}<0.05)$ than that of the other seeds, which have similar acid levels. This high value in L. siceraria (high amounts of free fatty acids) is due to that of L. siceraria from Bafoussam (22). The high acid values observed, which is due to the high amounts of free fatty acids present in these oils may be due to the method of processing of these seeds: Some of the seeds, once extracted from the fruits are left overnight or for 2 days to slightly ferment while some farmers allow the fruits to get rotten before the seeds are extracted from the fruit. This is in order to reduce the sticky and slimy nature of the content of the fruits for easy washing of the seeds. Fermentation favours the action of lipolytic enzymes, which hydrolyse the triglycerides in the seeds, liberating free fatty acids. After washing, the seeds are dried under the sun. If the sun is not hot enough, this drying can take a number of days before the seeds are completely dried. This slow drying causes the seeds to remain damp leading to slow fermentation. Secondly, the conditions, duration of storage of the seeds and the hot extraction of the oils too, can increase the acid index. This was also shown in the extraction of Butyrospermum parkii (Shea) butter, that acid index increases with temperature (Djeumako et al., 2000). These values are similar to those of Canarium schweinfurthii (410.01, Kapchie et al., 2000) and Ricinodendron heudelotii (njansan) oils (2-9.24, Aboubakar et al., 2000). The maximum acid index of edible oils is $15 \mathrm{mg} \mathrm{KOH} / \mathrm{g}$ of oil (Krisnamurthy, 1982). Most of the acid values for these egusi oils are below this level hence can be considered as good edible oils.

The saponification index is from 204 (C. maxima) to 231 (C. sativus). There is no significant difference between the saponification levels of these seeds. These values are slightly higher than those of C. sativus (191-197) and Cucumis melo (melon seed) oils (193) (Capelle, 1949); oils from Zea mays, corn (187-195); Gossypium hirsutum, cottonseed (189198); Sesamum indicum, (sesame) and Glycine max (soybean) (189-195); Helianthus annuus, sunflower (188-194); Arachis hypogaea, peanut (187-196); Elais guineensis, palm (190-209) (Codex Alimentarius, 1999) and Olea europaea, olive oils (190-192) (Capelle, 1949). They are lower than those of oils rich in saturated fatty acids (SFA) such as Cocos nucifera, coconut (248-265) and Elais guineensis, palm kernel oils (230-254) (Codex Alimentarius, 1999). These values are also slightly higher than those of non-conventional oils such as Dacryodes edulis, the African pear (201.4) (Omoti and Okiy, 1987), Coula edulis (180-185) (Tchiégang et al.,1998), C. schweinfurthii (177-197.79) (Kapchie et al., 2000) and R. heudelotii oils (181198.02) (Aboubakar et al., 2000).

The iodine index of our samples ranges from 83 (C. moschata) to 114 (C. sativus). The iodine index of $C$. moschata is significantly lower $(\mathrm{p}>0.05)$ than that of the other seeds, which have similar iodine levels. These values are similar to those of $C$. sativus (115-118\%) and Cucumis melo (101) (Capelle, 1949) and to those of unsaturated fatty acid-rich oils such as peanut (86-107), cottonseed (100-123), sesame (104-120), sunflower (118-141), but lower than that of Glycine max, soybean oil (124-139). This high value of iodine index in soybean oil is probably due to its high level of linolenic acid (4.5-11\%) (Codex Alimentarius, 1999). They are higher than those of saturated fatty acid-rich oils such as Theobroma cacao, cocoa butter (32-42) (Capelle, 1949), coconut (6-10.6), palm (50-55), palm kernel (14-21) (Codex Alimentarius, 1999) and C. edulis oils (90-95) (Tchiégang et al., 1998); but lower than those of C. schweinfurthii (116-152.8) (Kapchie et al.,2000) and Ricinodendron heudelotii oils (140-169.77) (Aboubakar et al.,2000). The iodine index, which indicates the level of unsaturation in oils, shows that these oils (except C. moschata) have high levels of polyunsaturated fatty acids, hence can be considered as siccative oils (Hilditch, 1947).

The peroxide index of our samples ranges from 3 (L. siceraria) to 8 m.equiv.g of $\mathrm{O}_{2} / \mathrm{kg}$ of oil (C. mannii) except C. moschata (20). The peroxide index of C. moschata is 
significantly higher $(p<0.05)$ than that of the other seeds, which have similar peroxide levels. The peroxide index depends on a number of factors such as the state of oxidation (quantity of oxygen consumed), the method of extraction used and the type of fatty acids present in the oil. The high peroxide value in some of these oils may be due to much exposure of the seeds to the sun during drying, causing lipid oxidation resulting from the absorption of oxygen, which increases the formation of peroxides. Secondly, it can be due to heating of the oil during its extraction. Heat favours oxidation of fatty acids increasing the formation of peroxides (Cheftel and Cheftel, 1992). Thirdly, these oils contain mostly polyunsaturated fatty acids (especially L. siceraria), which easily undergo oxidation, raising peroxide values in these seeds. They are lower than those of $R$. heudelotii oils (19-114) (Aboubakar et al., 2000). Most of our values are lower than $15 \mathrm{~m}$.equiv.g of $\mathrm{O}_{2} / \mathrm{kg}$ of oil (the maximum level for cold pressed and virgin oils, Codex Alimentarius, 1999), showing that these oils are good edible oils.

The percentage of impurity (acid/saponification index) ranges from 1.49 (C. mannii) to 4.63 (L. siceraria). The percentage of impurity of $L$. siceraria is significantly higher than that of the other seeds, which have similar levels. These oils were extracted under heat and analysed for quality without purification. The high percentage of impurity (high amounts of free fatty acids) in some of these oils may be due to the methods of processing, the conditions and duration of storage of these seeds and the method of extraction used in the laboratory.

Table 3 shows the fatty acid composition of the oils. 4 main fatty acids are found in these oils: Palmitic, C16:0 (10-19\%); stearic, C18:0 (7-11\%); oleic, C18:1 (9-25\%) and linoleic, C18:2 (48-69\%) acids, amounting to 96-99\%. Linoleic $>$ oleic $>$ stearic acid for all the samples, irrespective of the region of cultivation. Palmitic is also $>$ stearic acid in all the samples except $C$. sativus with similar levels of these 2 fatty acids. The level of C16:0 in $C$. moschata is similar to that of $C$. mannii, but significantly higher $(\mathrm{p}<0.05)$ than that of the other seeds, which have similar levels. The C18:0 level in $C$. mannii is similar to that of $C$. sativus, but significantly higher $(\mathrm{p}<0.05)$ than that of the other seeds. The $\mathrm{C} 18: 1$ level in $C$. maxima is significantly higher, while that of $L$. siceraria is significantly lower $(\mathrm{p}<0.05)$ than that of the other seeds. The C18:2 level in L. siceraria is similar to that of C. sativus but significantly higher than that of the other seeds.

The content in saturated fatty acids (SFA) ranges from 21 (L. siceraria and $C$. maxima) to $30 \%$ (C. mannii and C. moschata), which is significantly higher $(\mathrm{p}<0.05)$ than that of the other seeds, which have similar levels. The monounsaturated fatty acid (MUFA) level in C. maxima (25.3\%) is significantly higher, while that of L. siceraria is significantly lower $(9.05 \%)$ than that of the other seeds. The level of polyunsaturated fatty acids (PUFA) ranges from 49 (C. moschata) to $69.58 \%$ (L. siceraria). This PUFA level of $L$. siceraria is similar to that of $C$. sativus but significantly higher $(\mathrm{p}<0.05)$ than that of the other seeds. That of unsaturated fatty acids (unSFA) ranges from 68 (C. moschata) to 78.63 (L. siceraria) with no significant difference between these values. This shows that these oils are good sources of unSFA, mostly PUFA, with linoleic acid (an essential fatty acid) being the most abundant (48-69.13\%). Linoleic acid is the most important essential fatty acid, for it must be got from food. This is because, during the synthesis of unsaturated fatty acids, oleic acid (C18:1) can easily be formed from stearic acid (C18:0). That is, the desaturation of stearyl-CoA to form oleyl-CoA occurs readily in the mammalian liver:

$$
\text { Stearyl-Co A }+\mathrm{NADH}+\mathrm{H}^{+}+\mathrm{O}_{2} \rightarrow \text { Oleyl-Co A }+2 \mathrm{H}_{2} \mathrm{O}+\mathrm{NAD}^{+}
$$

On the other hand, the desaturation of oleyl-CoA which is supposed to form octadecadienoic acid (linoleic acid) is not possible. However, the desaturation of linoleic acid is possible with the formation of 2 products: $\alpha$ - linolenic acid (in plants) and $\gamma$ - linolenic acid (in animals). $\gamma$ linolenic acid, though found only in very small quantities in animal fats, is an intermediate in the formation of arachidonic acid (Ottaway and Apps, 1984). Linoleic acid is therefore an essential component of the diet. An adult needs $10 \mathrm{~g} /$ day. These egusi seeds are therefore good 
sources of linoleic acid. The linoleic acid level in these seeds is similar to that of egusi seeds from Niger (30-74\%) (Silou et al., 1999). These results show that these egusi oils are better than animal fats in their content of linoleic acid, while animal fats contain mostly oleic acid (29-48\%, NRC publication No. 575 ). Our results for melon seeds are also similar to those of previous studies on Cucurbita pepo seed oil which was found to contain mostly palmitic, stearic, oleic and linoleic acids, with linoleic acid as the most abundant (Muckovic et al., 1996 and Younis et al., 2000). These values are different from those of Idouraine et al. (1996) and Zdunczyk et al. (1999) who showed that C. pepo seeds contain oleic acid as the most abundant fatty acid. The linoleic acid content of these oils (especially L. siceraria) is similar to that of Carthamus tinctorius, safflower oil, which has one of the highest linoleic acid contents (70\%) (Codex Alimentarius, 1999). Our values are also similar to those of corn, cottonseed, sunflower, soybean and sesame oils, (similar fatty acid profile to egusi seeds and linoleic acid as the most abundant). They are different from those of peanut and palm olein oils, (oleic acid is the most abundant) and palm and coconut oils (contain mostly unsaturated fatty acids, C16:0 and C12:0 respectively) (Codex Alimentarius, 1999). These values are somehow also similar to those of non-conventional oilseeds. D. edulis oil has palmitic, oleic and linoleic acids, amounting to 95\% (Bezard et al., 1991) and the African pulp oil $(63.4 \%$ pulp) is also rich in these 3 fatty acids (Kapseu and Tchiégang, 1996). These egusi oils are very poor in linolenic acid (0.1-0.22\%). Though linolenic acid is an omega-3 fatty acid with positive health effects, it easily oxidises and it is undesirable in edible oils because of the offflavours and potentially harmful oxidation products formed. Warner and Gupta (2003) showed that decrease in linolenic acid from 2 to $0.8 \%$ in oils, improved flavour quality and oxidative stability of fried foods. This shows that for oil to be very good for frying, its linolenic acid level should be less than $1 \%$, as in these egusi oils. These oils can therefore be used as frying oils. Looking at the composition of these seeds, the best oils to be considered as sources of essential fatty acids should be those with the lowest possible value of $\mathrm{R}_{1}$ (oils with the highest levels of linoleic acids). $\mathrm{R}_{1}$ is the ratio of saturated fatty acids to that of unsaturated fatty acids. This $\mathrm{R}_{1}$ ranges from 0.27 (L. siceraria) to 0.45 (C. mannii), showing that $L$. siceraria is the best source of essential fatty acid among these egusi oils. Therefore, considering the linolenic acid levels and $\mathrm{R}_{1}$ values (from the lowest to the highest values of linolenic acid and $\mathrm{R}_{1}$ ) of these oils, they can be classified in decreasing order of importance as follows: $L$. siceraria $>C$. sativus $>C$. maxima $>C$. moschata $>C$. mannii.

\section{CONCLUSION AND RECOMMENDATIONS}

This study shows that the saponification, iodine and peroxide indices of these egusi seed oils from Cameroon depend on the regions while the acid index and percentage of impurity of the seeds do not depend on the region of cultivation but on the specie. Their acid and peroxide levels are within recommended limits, but can be excellent if these oils are purified. The saponification indices are slightly higher, while the iodine indices are closer to those of unsaturated fatty acid-rich oils (corn, cottonseed, sesame, sunflower and peanut oils), showing that they are rich in unsaturated fatty acids. These egusi oils are very rich in essential fatty acids (linoleic acid) but poor in linolenic acid especially L. siceraria. Their fatty acid profile follows the same pattern as that of corn, cottonseed, soybean and sesame oils. The linolenic acid level of these egusi oils is much lower than that of soybean. The acceptable acid and peroxide values, high linoleic and low linolenic acid levels of these oils suggest they can be sources of edible oils such as table oils, cooking and frying oils, making them good for the fight against cardiovascular illnesses. They can also be used to make mayonnaise. These oils have higher linoleic and lower linolenic acid levels than animal oils. This makes them less oxidisable, hence, good edible oils. 
Further research is being carried out to study the physical properties of these oils, the lipid composition and the atherogenicity of these oils in vivo.

\section{ACKNOWLEDGEMENT}

Part of this research was supported by the International Foundation for Science, Stockholm, Sweden and The Organisation for the Prohibition of Chemical Weapons (OPCW), THE HAGUE, Netherlands, through a grant to Mrs ACHU Mercy Bih. We are also very grateful to Dr Kansci Germain for helping us to carry out the fatty acid analysis of this work.

\section{REFERENCES}

Aboubakar, D. A. K., Tchiégang, C., Ndjouenkeu, R., Kapseu, C. and Mbofung, C. M. (2000). Caractéristiques morphologiques des Amandes et physico-chimiques de l'huile de Ricinodendron heudelotii (Bail.) du Cameroun. 3rd International Workshop on the improvement of Safou and other non-conventional oil crops. Yaoundé, Cameroon. Pp 288-297

Achu, M. B., Fokou, E., Tchiégang, C., Fotso, M. and Tchouanguep, F. M. (2005). Nutritive Value of some Cucurbitaceae Oilseeds from Different Regions in Cameroon: African Journal of Biotechnology, 4 (10), 1329-1334

AFNOR (1981). Corps gras, graines oléagineuses, produits dérivés. Recueil de normes françaises. AFNOR, 438p. $2^{\mathrm{e}}$ ed. Paris, France.

AOAC (1980). Official Methods of Analysis of the Association of Official Analytical Chemists. $13^{\text {th }}$ ed. William Horwitz ed. Pp 56-132. Washington D.C. 7.

Bezard, J., Silou, T., Sempore, G. and Kiakouama, S. (1991). Study of Dacryodes edulis: Variation of the composition of the glyceridic fraction for safou pulp (pear tree) during ripening. Revue Francaise de Corps Gras, 38 (7-8), 233-241.

Capelle, G. (1949). Matières Grasses. In: Traité Pratique de Chimie Végétale a l'usage des laboratoires et de l'agronomie métropolitaine et Coloniale. Tome 3. Edition Georges Frère. Pp 317-429. Tourciong.

Cheftel, J. C. and Cheftel, H. (1992. Introduction a la Biochimie et a la Technologie des Aliments. Technique et documentation, Pp 243-330 Paris Cedex, 1.

Codex Alimentarius (1999). Codex Alimentarius Standards for Fats and Oils from Vegetable Sources. Section 2. Codex Alimentarius Standards for Named Vegetable oils. Codex Alimentarius -Stan 210.

Djeumako, B., Kapseu, C., Fomethe, A. and Kamga, R. (2000). Extraction du Beurre de Karité par presse Manuelle: Contraintes. 3rd International Workshop on the improvement of Safou and other non-conventional oil crops. Yaoundé, Cameroon. 382-389

Fokou, E., Achu, M. B. and Tchouanguep, M. F. (2004). Preliminary Nutritional Evaluation of Five Species of Egusi Seeds in Cameroon. African Journal of Food, Agriculture, Nutrition and Development, 4 (1), 11p 
Hilditch, T. P. (1947). Chimie Industrielle des Corps Gras et de Cires.6, Pp 9-306. Rue de la Sorbonne 6. Paris.

Idouraine, A., Kohlhepp, E. A., Weber, C. W., Warid, W. A. and Martinez-Tellez, J. J. (1996). Nutrient constituents from eight lines of naked seed squash (C. pepo L.). Journal of Agricultural and Food Chemistry, 44 (3), 721-724.

Kapchie, N. V., Tchiégang, C., Mbofung, C. M. and Kapseu, C. (2000). Variation dans les caractéristiques physicochimiques des fruits de l'aiélé (Canarium schweinfruthii E.) de différentes provenances du Cameroun. 3rd International Workshop on the improvement of Safou and other non-conventional oil crops. Yaoundé, Cameroon. 249-262

Kapseu, C. and Tchiégang. C. (1996). Oil composition from two types of African pear in Cameroon. Fruits, 51(3), 185-191.

Kinkela, T. (1990). Utilisation des céréales et des oléagineux locaux au Congo. La Poste récolte en afrique. Actes des séminaires internationaux tenue a Abidjan. p203. Cote d'Ivoire. AUPELF- UREF

Krishnamurthy, R.G. (1982). Cooking oils, salad oils and salad dressings. In: Bailey's Industrial Oils and Fat Products. Vol 2. $4^{\text {th }}$ ed. (D. SWERN ed), John Wiley and Sons Inc. 603p. New York, USA.

Mampouya, D., Silou, T., Loka Lonyange, W. D. and Saadou, M. (2000). Composition globale et caractéristiques des huiles extraites de 5 espèces de Cucurbitacées du Niger. 3rd International Workshop on the improvement of Safou and other nonconventional oil crops. Yaoundé, Cameroon. Pp 264-274

Martin, F. W. (1998). Cucurbit Seed as Possible oil and Protein Sources. tropicalseeds.com: vegetables and herbs. ECHO, 17430. 7p. Durrance Rd., North Ft. Myers FL 33917, USA.

Murkovic, M., Hillebrand, A., Winkler, J., Leitner, E. and Pfannhauser, W. (1996). Variability of Fatty Acid Content in Pumpkin Seeds. (Cucurbita. pepo L) Zeitschrift-fuer-Lebensmittel-Untersuchung-und-Forschung, 203 (3), 216-219.

Ng, T. J. (1993). New Opportunities in the Cucurbitaceae. in: J. Janick and J. E. Simon (eds), New Crops. Pp 538-546. Wiley, New York.

NRC publication No. 575. The role of dietary fat in Human Health: A report. Food and Nutrition Board, National Academy of Science. 1p

Oil Crops (2000). Egusi Seeds are rich in Oil and Protein. Oil Crops/Processing. http://www.echonet.org/tropicalag/aztext/azch16oi.htm. Accessed 16/08/2000

Omoti, U. and Okiy, D. A. (1987). Characteristics and Composition of the Pulp Oil and Cake of the African Pear, Dacryodes edulis (Don, G.) Journal of the Science of Food and Agriculture, 38 (1), 67-72 
Ottaway, J. H. and Apps, D. K. (1984). Concise Medical Textbooks. Biochemistry. $4^{\text {th }}$ edition. 300p. London.

Silou, T. H., Mampouya, D., Loka Lonyange, W. D. and Saadou, M. (1999). Composition globale et caractéristiques des huiles extraits de 5 espèces de Cucurbitacées du Niger. La Rivista Italiana Delle Sostanze Grasse. LXXVI, 141-144

Tchiégang, C., Kapsue, C. and Parmentier, M. (1998). Chemical Composition of Oil from Coula edulis (Bail.) nuts. Journal of Food Lipids, 5, 103-111

Veljkovic, S. (1992). Nutritional and Dietetic value of Pumpkin (C. pepo, L.) Hrana-IIshrana, 33 (3/4), 137-139

Warner, K. A. and Gupta, M. (2003). Frying Quality and Stability of Low and Ultra Low Linolenic Acid Soybean Oils. Journal of American Chemists Society, 80, 275-280.

Younis, Y. M., Ghirmay, S. and Al-Shihry, S. S. (2000). African Cucurbita pepo L. Properties of Seed and Variability in Fatty Acid Composition of Seed oil. Phytochemistry, 54 (1), 71-75

Zdunczyk, Z., Minakowski, D., Frejnagel, S. and Flis, M. (1999)

Comparative Study of the Chemical Composition and Nutritional Value of Pumpkin seed cake, Soybean meal and Casein. Nahrun, 43 (6), 392-395 